\title{
Term - Deposit Waqf Linked Isthisna (TDWLI): Proposed Models, Accounting Aspects, and Risk Management Analysis
}

\author{
Yaser Taufik Syamlan \\ Director of Sharia Fintech Study Center Tazkia, Indonesia \\ email: yasersyamlan@tazkia.ac.id
}

\section{Sakinah}

Institut Tazkia, Bogor, Indonesia

email: ukhtisakinah@gmail.com

\section{Mursalmina}

Institut Tazkia, Bogor, Indonesia

email: arrisyadimursalmina@gmail.com

\author{
Asfa Asfiah \\ Institut Tazkia, Bogor, Indonesia \\ email: asfa.asfiah@gmail.com
}

\begin{abstract}
Islamic banking (further referred to as the Bank) faces two significant problems: excessive concentration in Murabaha financing contracts and high cost of funds. These two classic problems directly impact the development of the Bank and give rise to the stigma of a less innovative and unprofitable industry. This research aims to make a new product breakthrough that can help stakeholders overcome the two problems above. Term Deposit Waqf Linked Isthisna (TDWLI) has 4 variants: TDWLI Perpetual Principal, TDWLI Perpetual Principal + Profit Sharing, TDWLI Periodic Principal, TDWLI Periodic Principal, and + Profit Sharing. The TDWLI Periodic Principal is the variant that is most ready to be applied because, in accounting terms, it has been regulated in PSAK 112. In general, this TDWLI product will provide several advantages for banks to reduce the cost of funds (especially in the main variant of Waqf only). It will increase Isthisna financing, referring to OJK data in 2019, only $0.3 \%$ of total financing. In terms of accounting treatment, PSAK 112 must be adjusted especially if the Bank will release a Perpetual-based product variant. The main problem with perpetual-based products is the uncommon features. In perpetual, cash waqf cannot be withdrawn or, in other words, eternal. This research recommends that $\mathrm{OJK}$ is expected to study this product more deeply to develop healthy and innovative Islamic banking.
\end{abstract}

Keywords: Waqf; Isthisna; Social Finance; Risk Management Analysis 
Yaser Taufik Syamlan et al.

\begin{abstract}
Abstrak: Perbankan syariah (selanjutnya disebut Bank) saat ini sedang menghadapi 2 masalah besar yaitu konsentrasi berlebihan di akad pembiayaan Murabaha serta tingginya Cost of Fund. Kedua masalah klasik ini berdampak langsung kepada perkembangan Bank dan memunculkan stigma industry yang kurang inovatif dan tidak menguntungkan. Penelitian ini bertujuan untuk membuat terobosan produk baru yang dapat membantu stakeholders dalam mengatasi kedua masalah diatas. Produk Deposito Waqf Linked Isthisna (DWLI) dengan 4 varian nya baik itu DWLI Perpetual Pokok, DWLI Perpetual Pokok + Bagi Hasil, DWLI Periodic Pokok dan DWLI Periodic Pokok + Bagi Hasil. DWLI Periodic Pokok menjadi varian yang paling siap untuk diaplikasikan karena secara akuntansi sudah diatur dalam PSAK 112. Secara umum produk DWLI ini akan memberikan beberapa keuntungan bagi bank dalam rangka menurunkan cost of fund (terutama pada varian Wakaf pokok saja) serta akan menaikkan pembiayaan Isthisna yang merujuk kepada data OJK tahun 2019 hanya 0,3\% dari total pembiayaan. Secara perlakuan akuntansi, PSAK 112 harus disesuaikan terutama apabila Bank akan merelaisasikan varian produk berbasis Perpetual. Permasalahan utama dari produk berbasis perpetual adalah ketidak umuman fitur dimana dalam perpetual, Wakaf uang tidak dapat ditarik atau dengan kata lain abadi. Rekomendasi dari penelitian ini adalah OJK diharapkan dapat mengkaji produk ini lebih dalam demi perkembangan perbank syariah yang sehat dan inovatif.
\end{abstract}

Kata Kunci: Wakaf; Istina; Keuangan Sosial; Analisis Manajemen Risiko 
Term - Deposit Waqf Linked Isthisna (TDWLI): Proposed ...

\section{Introduction}

The development of the Islamic Bank cannot be separated from the overutilization of the Murabaha (Buy and Sale) contract (Hanif 2016), including the Islamic Bank in Indonesia (Ismal 2014; Mukhlisin, Hudaib, and Azid 2015). Murabaha benefits more to the bank since it is fixed and predetermined upfront. Thus, Murabaha is a favorite contract that is used in IB. However, due to its limitation, Murabaha can only serve the fixed asset financing (Rosly 2010).

To solve the Murabaha limitation, some researchers propose other buy and sale contracts, namely Isthisna. The recent one is from Hasmawati \& Mohamad (2019), which said its unique side would benefit all stakeholders. On the bank side, the bank can enter the transaction before the existence of the asset. While on the project owner side, since Isthisna requires manufacturing an asset or creating a project, the financing from the bank can handle both material and non-material items. Besides this, researchers like Farrukh (2010) and Manzoor et al. (2017) present the consequence of the Isthisna, which on the Islamic Bank side, gives more default risk of third-party fund compared to Murabaha.

To promote Isthisna as the alternative mode of financing, Zarqa (1997) provides an interesting point of view by stating that Isthisna is most suitable for social investment that focuses on developing public goods. He gave an example; the free public schools that the community in improving their education can utilize. There will be many benefits resulting from the project that the public can receive. The object produced can purely be perceived by the public. Mohsin (2013) also support the Zarqa (1997), Isthisna can be used for investment project using the Waqf fund. Waqf is a charitable contribution established with cash for personal dedication owned by a Muslim, group, or a legal entity regulated following sharia. The results of using Waqf are recognized by Islam (Mohsin, 2013).

Economica: Jurnal Ekonomi Islam - Volume 11, Nomor 1 (2020)

https://journal.walisongo.ac.id/index.php/economica 
Yaser Taufik Syamlan et al.

In Islamic Bank context, the Waqf fund can overcome the problem of high cost of funds (COF) Islamic banking in Bangladesh uses financial modification, namely the waqf mudharabah contract scheme in Islamic banking. Managing the waqf asset set will provide broader social benefits. Thus, apart from taking advantage of the waqf set of Waqif, which is channeled for bank social investment, also does not have a profit-sharing burden that must be paid later. Other banks in Bangladesh like Exim Bank, Shahjalal Islami Bank, and other banks in Bangladesh have implemented cash waqf deposits as a product that can provide opportunities for wealthy people to invest in charities in sociallyform projects beneficial (Thoarlim, Rahman, and Yanya 2017).

Islamic banking in Bangladesh made effort to reduce the cost of funds (COF) in the country by utilizing the accumulation of Waqf through a banking contract scheme that has been modified to become "Cash Waqf Mudharabah". However, based on the banking problems in Indonesia as described earlier and seeing the potential, Waqf in Indonesia cannot be utilized or distributed optimally (Tanjung 2018). Islamic banking with stakeholders can work together to distribute the set of Waqf and do social investment using a modification scheme that can also reduce the problem of small isthisna' financing numbers and the increasing Cost of Fund (COF) gap in Islamic banking. So, it is necessary to have a modified product of Islamic banking (further referred to as the Bank), which can reduce or even eliminate this problem through the Term Deposit Waqf Linked Isthisna (TDWLI). This paper will address four research questions: (1) What is the model and the feature of TDWLI? (2) How is the accounting aspect of TDWLI (3) How is the risk analysis and mitigation in TDWLI?

\section{Literature review}

\section{Isthisna}

Isthisna 'is a special sale-purchase contract, referring to the fiqh hanafi school akad isthisna' being exempted from several applicable fiqh regulations 
because it has a unique nature (Zarqa, 1997). Sale and purchase contract such as a murabahah is an order to buy goods or commodities that already exist or can be found in the market. Meanwhile the isthisna 'financing instrument is an agreement contract in which the goods or commodities do not exist until the contract has been completed (Farrukh 2010). Thus the isthisna 'contract is an agreement between the seller and the buyer with a customized commodity. The asset or item will be built or produced according to the request of the buyer. The request is completed with precise specifications and agreed upon by the parties concerned that the goods will be delivered or received at the time which will come and at a predetermined price (BNM 2014). Therefore, the seller is obliged to produce an object. Specifically, production here includes all processes of manufacture, construction, assembly, and packaging of products or buildings that are the object of sale. However, besides that, other parties can carry out the work while still under the supervision and responsibility of sellers (IDB, 2002).

Istisna has some differences compared to the salam financing system in the banking context, and the difference lies in the payment method. If the salam financing system requires payment in advance, the isthisna 'contract can pay in installments that must be paid at the beginning, middle, or the end of the agreement. The customer pays the bank in installments. This can be done in a factory or in construction. The mechanism is that the customer requests a product or construction according to the customer's specifications, but the goods are not there yet or are still in process.

Furthermore, the bank looks for a manufacturer or a contractor to acquire or carry the goods or products referred by the customer. After meeting with the manufacturer or supplier, the bank negotiates. When they agree, an initial agreement will provide payment in installments for the goods or products to be purchased. After the goods arrive, the manufacturer or supplier sends the goods or products to the bank to be given to the customer or the bank through the manufacturer or contractor to deliver the goods with special 
Yaser Taufik Syamlan et al.

specifications. After customers receive the goods or products in question, they will pay the bank in cash or installments (Hasmawati and Mohamad 2019).

\section{Waqf}

The fiqh experts have discussed the concept of waqf Perpetual (eternal) and periodic (temporary), both principal and principal + margin. The majority of fiqh expert such as the Maliki, Shafi'i and Hanbali schools argue that Waqf is common (mandatory and binding). Because of the mandatory status, it gives consequences to the Waqif (property waqf) for the prohibition of withdrawing items that have been waqfed during the contract. This opinion refers to the incident of Umar bin Khattab who obtained land in the khaibar then he asked the Prophet "O Messenger of Allah, I got land in the khaibar, I have never had this kind of wealth at all, what do you order me?" Prophet Sallalallahu alaihi wasallam replied, "If you want, you can hold (mercy) the land and donate the results of the land on the condition that it cannot be sold, granted, and not inherited".

Another opinion is the opinion of Imam Abu Hanifah that forgiving goods does not result in the loss of the goods being donated from the ownership of the person who forgives. Therefore, because the Waqif may withdraw the Waqf, it is also permissible to sell it because the legal Waqf is ja'iz (acceptable), not common (mandatory and binding). However, on the other hand, two of Imam Abu Hanifah's students, whose opinions were both used as fatwas among the hanafiyyah school, had the same opinion as to the first opinion, namely the majority of fiqh experts (AAOIFI, 2015).

Auditing and Accounting Organization finance Institution (AAOFI) allows the practice of periodic Waqf as stated in number 33 point 3.1.4 (AAOIFI 2015). This opinion refers to the argument narrated by al-Qadhi Shuraih, who said, "Prophet Muhammad Sallallahu alaihi wasallam came to sell waqf goods". The above statement shows that most jurisprudence experts legalize perpetually and reject periodic in all its forms. However, which Perpetual 
Waqf is legalized, whether principal perpetual or principal perpetual + Margin. Fiqh experts have also reviewed the practice of Waqif, which forgives the goods but requires the results of the management of the Waqf back to the Waqif, which is often termed the main Perpetual Waqf. The first opinion that it is permissible for Waqif requires the results of waqf management for Waqif himself, this is the opinion of the Hanbali and Abu Yusuf mazhab from the Hanafi school of thought. The second opinion is that it is not justified for Waqif to require the waqf management results for himself. This opinion is the most authentic in the Syafii school of thought. The implication of the above is that the main perpetual Waqf or the main Perpetual + Margin has a difference of opinion among the scholars, where the most valid mazhab in the syifii mazhab legalizes the main perpetual Waqf + Margin but not the main Perpetual Waqf. In contrast, the Hanbali School legalizes the two forms of Waqf (Fuadi 2018).

Above Waqf literature review will impact the TDWLI product. TDWLI Practice begins with the delivery of a sum of money from the customer to the Islamic party as a nadhir to be debited to the Customer's Deposit account. Fiqh experts have different opinions about Waqf with currency because some require that waqf subject must be in the form of goods that can be used and the goods have perpetuity. The Assyafii school and the Hanbali school prohibit the practice of Waqf in cash (Dirham and Dinar) and other items that are taken advantage of by eliminating their other goods. The Hanafi and Maliki schools argue that it is permissible to waqf dirhams and dinars if they have become a habit and must be converted to immovable objects. The MUI DSN fatwa allows money waqf issued its decision on May 11, 2002. Likewise, the AAOFL fatwa that it is permissible to forgive money as long as it does not use the money for things that have lost/perished in the form of money, how to use the money is like investing it in other things allowed by sharia. 
Yaser Taufik Syamlan et al.

\section{Methods}

In this study, researchers used descriptive analysis techniques, where descriptive research is a form of research that describes existing phenomena, both natural phenomena and man-made phenomena. These phenomena can be in the form of activities, characteristics, changes, relationships, similarities, and differences between one phenomenon and another. Descriptive analysis is also research that tries to describe and interpret something. Descriptive research is designed to obtain information about the conditions of the research being carried out (Loeb et al. 2017).

There are four steps in carrying out a descriptive analysis (Loeb et al. 2017). It starts with Problem Identification $n$ identifying the problem. For example, the researcher looked at the current state of Islamic banking, which is facing issues with the low number of isthisna 'contract financing in Islamic banking and the high number of profit-sharing expenses or Cost of Fund (COF) in Islamic banking. However, Indonesia currently has many waqf lands and is widespread but has not been managed optimally. The second step is formulating problems. The problem formulation process is carried out by exploring national and international journals relevant to the research. Then researchers conclude the problem of the object of study and then provide solutions to these problems. The third step is Finding Basis. In looking for a theoretical basis in research, researchers use references to journals or previous studies that have discussed the variables in this study, namely Waqf, and isthisna '. The last step is Compiling Conclusions/Research Results. In the preparation of conclusions or research results, the researcher uses the steps above in the formulation of research conclusions. After the research, the researcher provides solutions to the problems identified in this study. The research result will be started by explaining the marketing, finance, and operation aspect of the TDWLI using the business model canvas introduced by Osterwalder and Pigneur (2010). 


\section{Result and discussion}

\section{TDWLI canvas business model formulation; waqf and isthisna integration.}

Table 1. TDWLI Canvas Business Model

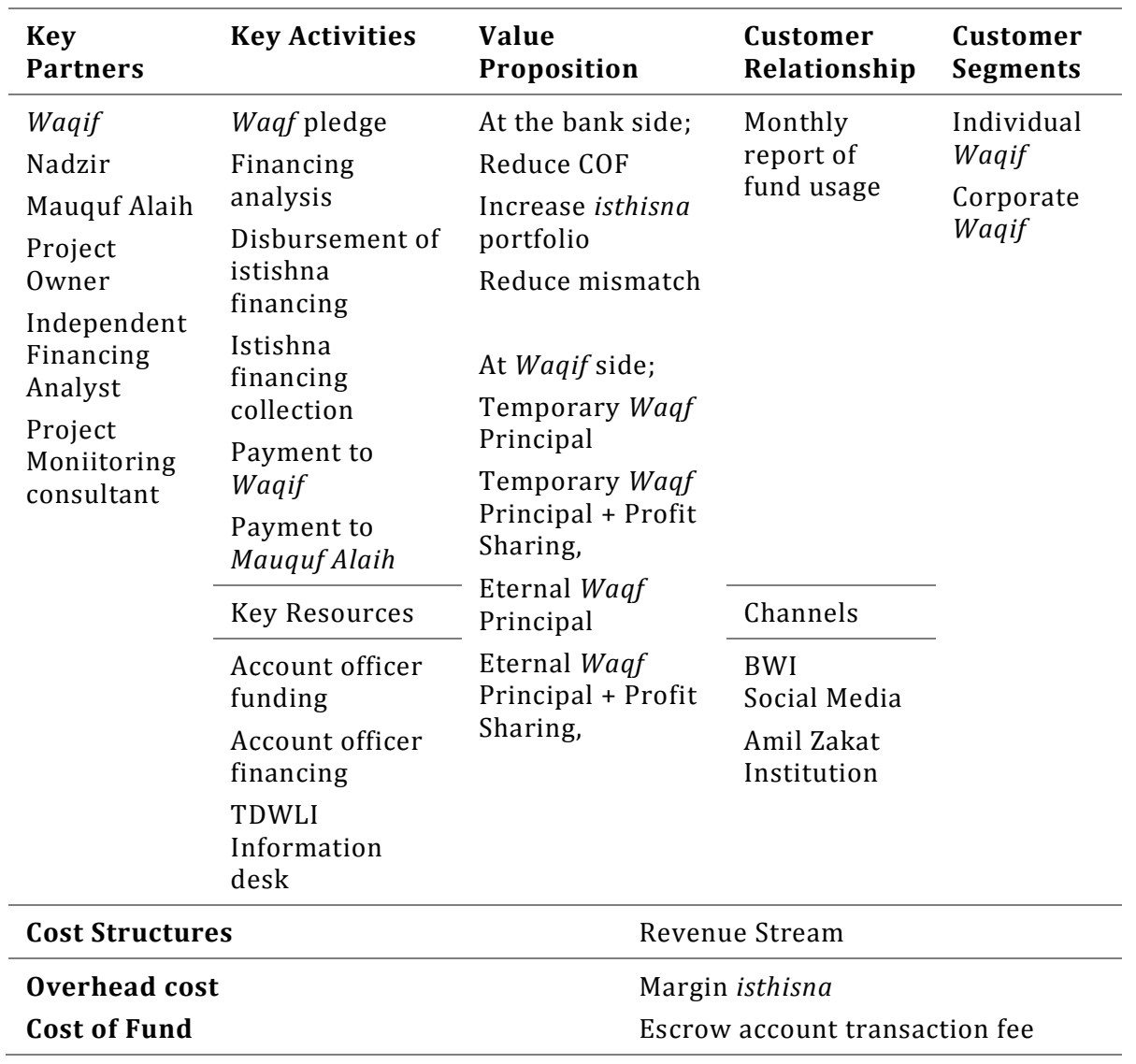

Source: (Darsono et al. 2017; Ahmad 1987; Manzoor, Karimirizi, and Mostafavisani 2017;

IAI 2018)

Economica: Jurnal Ekonomi Islam - Volume 11, Nomor 1 (2020) 
Yaser Taufik Syamlan et al.

Referring to Table 1. above, the TDWLI product proposal based on the canvas business model has 3 important aspects: marketing, operational and financial. The marketing aspect of TDWLI consists of value proposition, customer segment. TDWLI's Value Proposition is divided into two, namely the bankside and Waqif. For banks, this TDWLI is expected to reduce the high COF, which has been the main problem with the low profitability of Islamic banks. Furthermore, referring to the use of the financing agreement Isthisna in the Bank's framework to project future profits, considering the main features of this sale and purchase agreement are fixed in terms of principal returns and margins. Another main objective of TDWLI is to increase portfolio, Isthisna's which is currently below $1 \%$ of the total financing portfolio. Finally, TDWLI will use the Allocation of Fund system described by Darsono et al. (2017). The distribution of TDWLI to Isthisna financing must be adjusted to the time series Waqif's placement.

On the side Waqif, will be given the flexibility to choose the type of Waqf whether it is eternal (Perpetual) or temporary (Periodic). For Perpetual Waqf (Ahmad 1987), although this is outside of the generality described in PSAK 112 concerning Waqf, which in general discusses temporary money waqf, in this study, it will also be proposed to provide options to Waqif. Perpetual Waqf will be divided into two types, namely in the form of Principal Perpetual Waqf where Waqif donates the principal through the Bank and passes on to Mauquf Alaih only receives the proceeds from the management of Waqf funds. Furthermore, this type of perpetual Waqf also has a second type, Principal Perpetual Waqf and Margin (further referred to as Perpetual Principal + Margin TDWLI), where Waqif will donate the funds permanently both principal and margin without being returned. In this type, at the beginning of the Pledge, Waqif would mention the Mauqud Alaih that would benefit from the funds. The next type of waqf deposit product is Periodic or in PSAK 112 it is also called temporary Waqf (IAI 2018). such as the TDWLI Perpetual, this type also has a variant that allows Waqif to donate all of his funds, both 
principal and profit-sharing, or only donating the principal of TDWLI. For the first type of TDWLI Periodic Principal + Profit Sharing, Waqif here will not receive proceeds from deposits during the placement period. For Waqif who wants the results of their placement, they can only choose the Main Periodic TDWLI.

Moving on to the customer segment, TDWLI will be offered to individual Waqifs (Candra and Rahman 2010) and also Corporate Waqifs. Waqif Corporate, in this case, can be received from all types of business entities permitted by the Bank's internal SOP to support the CSR that is obliged by the government (Raimi, Patel, and Adelopo 2014). Following PSAK 112, Banks which in this TDWLI act as Nadzir are required to report to Waqif at least concerning accounting policies, Waqif that have ties, use of funds, and investment returns from Waqf (IAI 2018). The PSAK 112 requirement will bring the landscape of the customer relationship. To promote this TDWLI product, the Bank can create advertisements to be distributed to Waqif candidates through 2 channels: via social media and through amil zakat institutions such as BWI, BAZ/LAZ, and OPZ. Those are the channels of promoting the product.

Referring to Table .1, the next aspect is related to the operational side of TDWLI, in this case, Key Activates, Key Partners, and Key Resources. The first critical activity carried out in this process is the Waqf Pledge process carried out by Waqif during the deposit opening process. In this pledge, Waqif must mention Mauquf Alaih, especially when choosing the TDWLI Perpetual/Periodic Principal + Profit Sharing product types. As for TDWLI Perpetual/Periodic Principal products, Waqif must mention the beneficiaries who will only get the benefits of this type of TDWLI principal. The next activity is the bank's management of TDWLI funds; before the financing is given, the Bank will conduct a financing analysis. With the completion of the financing analysis, the disbursement of financing through the Isthisna scheme can be carried out as long as all conditions for disbursement are met without any 
Yaser Taufik Syamlan et al.

deviation from conditions. The bank will then carry out the next task, namely the Bank to collect from debtors, either Mauquf Alaih in the TDWLI Perpetual/Periodic Principal or to Project Owners who carry out projects that are useful to the ummah in general. In the end, Isthisna installment billing will make it easier for the Bank to calculate the profit before it is distributed to Waqif in the TDWLI Perpetual/Periodic Principal or given to Mauquf Alaih in the TDWLI Perpetual/Periodic Principal + Profit Sharing type (Cizakca 2014).

The key stakeholders of TDWLI are Waqif, Nadzir of Waqf Land, Project Owner (Project Owner), Independent Financing Analyst, and Project Monitoring Consultant. Waqif, in this case, is the depositor who decides to do Waqf through the TDWLI product in Islamic banking. Nadzir of the land in this case is the manager of the land who will receive Waqf funds, either in principle or along with the results. Nadzir of Waqf Land can also become Mauquf Alaih and will only get TDWLI principal when Waqif decides to take the proceeds from the management of Waqf by the bank. On the other hand, Nadzir of Waqf Land will get the principal and profit-sharing at the same time when in the process of the Waqif Pledge stated so (Noor and Yunus 2014).

Furthermore, another critical party is Mauquf Alaih, who will receive the benefits of Waqf; both the principal of the fund and the profit sharing. In this TDWLI scheme, the Project Owner is also required. Primarily when the TDWLI Principal + Profit Sharing is implemented on the condition that the Project Owner can work on projects that have a high level of benefit to the community; such as power plants, toll road projects, and other infrastructure projects (Tanjung 2018). Finally, the Bank can appoint an Independent Financing Analyst and also a Project Monitoring Consultant if needed. Both parties can be utilized to maintain independence from the financing selection process and a Project Monitoring Consultant who can assist the Bank in preparing monthly reports on the use of funds.

Account Officer (AO), which in this scheme is divided into AO Funding and AO Financing. AO Funding will be tasked with finding potential Waqif for 
TDWLI products and performing maintenance on Waqif monthly by forwarding the monthly fund usage reports made by AO. AO Financing is in charge of drafting a financing memorandum and passing it on to the financing committee. After being approved, AO Financing then monitors the disbursement process to the Debtor to monitor the financing. AO Financing; which is a crucial resource of TDWLI. Another vital resource that makes AO Funding/Financing easier is the TDWLI Information Desk (DID). The main task is to summarize all data from AO Financing, especially related to the management of Waqf funds and information about the results of profits on investment activities by the Bank as Nadzir in a monthly report to comply with PSAK 112 requirements (IAI 2018).

The final aspect of the canvas business model is the financial aspect that will support the marketing and operational aspects above. The fixed costs of TDWLI are Overhead Cost (OHC), which consists of employee salaries, utility bills such as office rent and electricity, and depreciation and asset maintenance costs. TDWLI's variable cost is the Cost of Fund (COF), which depends on the agreement between the Bank and Waqif. On the side Revenue Stream, the main source of income TDWLI's is the margin from Isthisna's financing. Therefore, the difference between margin Isthisna on the income side and OHC plus COF on the cost side will be the net profit that the Bank can book. In addition, periodic escrow transaction fees will be obtained when the transaction is made.

\section{Feature summary TDWLI}

The Deposit business model Term Deposit Waqf Linked Isthisna (further referred to as $T D W L I$ ) is a transaction in which the bank's position is the representative of Waqif to manage waqf funds based on buying and selling. In this business model, one Waqif acts as the donor of cash waqf, which will be distributed by the bank in the form of Isthisna-based financing. There are 4 variants of DWLI. The first one is TDWLI Perpetual Principal + Profit Sharing;

Economica: Jurnal Ekonomi Islam - Volume 11, Nomor 1 (2020) https://journal.walisongo.ac.id/index.php/economica 
Yaser Taufik Syamlan et al.

The Waqif in this product variant donates all of the funds, both the principal of the Waqf and the profits on the investment of waqf funds that the bank has managed. As the name implies, Waqif submits waqf funds perpetually, or in other words, perpetual and irrevocable. The second type is TDWLI Perpetual Principal; The main feature of this variant is that Waqif only donates the principal of Waqf permanently without being able to be cashed. Therefore, Waqif in this variant can enjoy the results of the management of waqf funds by the bank every month. The third type is TDWLI Periodic Principal + Profit Sharing; The Waqif in this product variant donates all the principal funds from the Waqf within a certain period, such as 1,3,6, or 12 months. At maturity, Waqif will get back the principal of this deposit. The last type is. TDWLI Periodic Principal; The Waqif in this product variant endorses the principal of the Waqf only within a certain period, such as $1,3,6$, or 12 months. Within this period, Waqif will receive the profit-sharing every month and get the principal back when due.

Table 2. Summary of TDWLI Features; Source: Variuos

\begin{tabular}{ll}
\hline \multicolumn{1}{c}{ Product Features of Deposit Linked Waqf Isthisna } \\
\hline Product Variant & 1. TDWLI Perpetual Principal + Margin \\
& 2. TDWLI Perpetual Principal \\
& 3. TDWLI Periodic Principal + Margin \\
& 4. TDWLI Periodic Principal \\
\hline Bank Role & Nadzir on Endowments Money \\
\hline Financing objectives & Perpetual *: financing land endowments/financing \\
& long-term infrastructure \\
& Periodic $*$ financing donated land/short-term \\
& financing for infrastructure endowment \\
& *The entire financing will be channeled through \\
& Isthisna contract \\
\hline Period & Perpetual \\
& Periodic 1,3,6, 12, 24 Months \\
\hline Return & Fixed either side of the bank or Waqif TDWLI which \\
& only donates the principal of deposits. \\
\hline Guarantee from Deposit & Guaranteed \\
\hline insurance agency & Fee + Margin (IAI 2018) \\
\hline Bank Income & On Balance Sheet (IAI 2018) \\
\hline Recording &
\end{tabular}


The role of the Bank is projected to be different in each type of product. In a perpetual type, the Bank purely positions itself as the Nadzir of this Waqf because of its irrevocable nature of endowments. For perpetual product types, actually, because the term is bound or muqayyad according to the agreement, Waqif represents waqf funds to be managed by the Bank in financing Isthisna. In addition, the Bank also positions itself as the representative of the asset owner to manage the Waqf fund both for its principal and its benefits and to be the representative for Waqif when the work handover process is carried out. On theside, the funding bank is obliged to calculate and distribute profit sharing to Waqif, who chooses TDWLI Perpetual/Periodic Principal only in proportion to the nominal deposit. This TDWLI product provides multiple benefits to banks, especially when receiving TDWLI, who donates the principal along with the profit sharing. Profits will arise, considering that the TDWLI funds will be channeled into commercial financing based on Isthisna.

Furthermore, TDWLI Principal + Profit Sharing will reduce the Cost of Fund so that the pure Isthisna margin will belong to the Bank. In this case, the bank acts as a monitor for the project's progress carried out by the project owner. Every month, the bank will provide project progress reports to reduce the risk of asymmetric information. Banks also play an active role in this transaction as financing analysts, collateral managers, escrow account service providers, and principal and margin payment agents. We recommend that TDWLI guaranteed fully by LPS since the waqf principle of AAOIFI requires the Nadzhir to protect the Waqf value (AAOIFI 2015). By doing all the above things, Banks will get income from 2 sources, namely Ujrah from TDWLI periodic and profits from the use of waqf funds through Isthisna financing. The recording is done on the balance sheet because of the generality of time deposits Third Party Fund (DPK) products. 
Yaser Taufik Syamlan et al.

\section{TDWLI flow process}

Below is the general TDWLI scheme used to finance Mauquf Alaih which owns Waqf land:

Figure 1. Scheme TDWLI for Mauquf Alaih who owns Waqf Land.

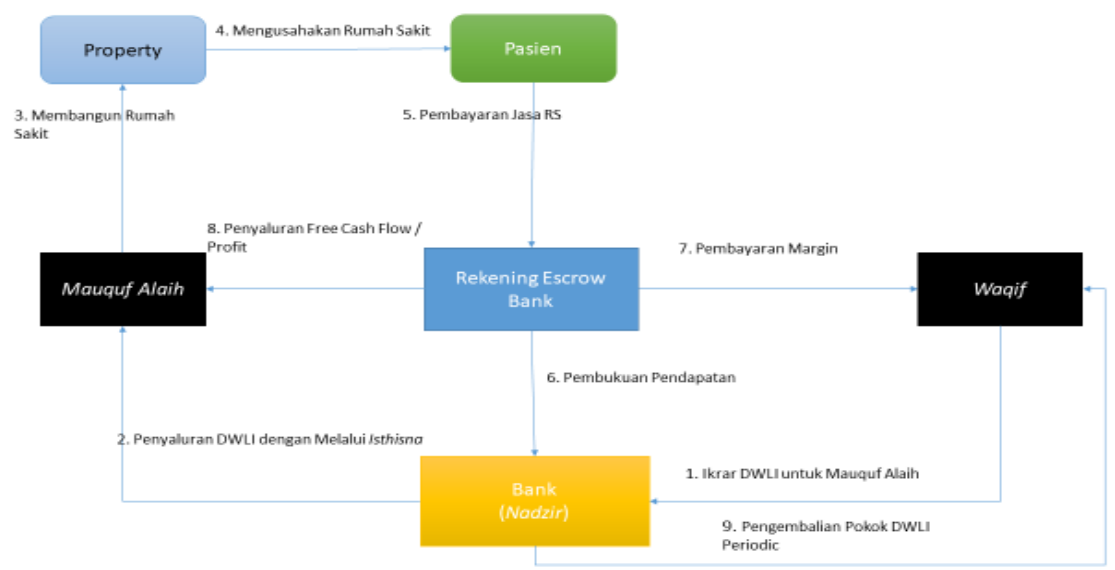

Source: Noor \& Yunus, (2014) with some modifications

The explanation of the above scheme is (1). Waqif pledges Waqf through TDWLI products by mentioning the type of Waqf, whether it is perpetual/periodic, either donating the principal or sharing the results at once. In terms of financing waqf land belonging to certain Mauquf Alaih. For example, PP Muhammadiyah (PPM) has a waqf land that will be used to become a hospital in an area and tries to get its members to donate money to build the project (Medias, Pratiwi, and Umam 2019). Regarding this case, Muhammdiyah members who want to do Waqf through TDWLI are obliged to mention Mauquf Alaih (PPM) as the beneficiaries of waqf benefits either in the form of TDWLI principal or for the results. (2) The bank, in this case as Nadzir, receives funds from Waqif to be recorded in the bank's liabilities to become Deposit Waqf linked Isthisna. (3) The bank then disbursed financing under the 
Isthisna contract, where the disbursement was made in stages according to the project's progress. After the project is completed, the bank represents Waqif to hand over the hospital to Mauquf Alaih, PPM. (4) PPM then runs the hospital's business operation. (5) All income from the patient, either from insurance or cash, must be channeled through the escrow account of the sharia bank that finances the project. (6) The bank then uses a scheme cash waterfall, which is responsible for using the escrow account. At the end of the month or when the installments are due, the bank will debit the installments Isthisna according to the initial agreement between the Bank and Mauquf Alaih. For example, Isthisna's financing margin is equivalent to $13 \%$ per year, where the COF to Waqif is $4 \%$. After the bank has recorded the income, the bank will calculate the portion of the profit to the Waqif and the amount of operational costs that will be given back to Mauquf Alaih to rerun his business. (7) The bank transfers funds from an escrow account equal to 4\% COF (from a total margin of $13 \%$ ) to be distributed proportionally according to the TDWLI amount given by Waqif to the Bank. (8) The bank, after sharing cash inflows with the cash waterfall at point 6 , then transfers the operational funds for the following month to PPM. In addition, it is also possible for the Bank to channel a $4 \%$ profit to Mauquf Alaih when the Waqifs choose TDWLI Perpetual Principal and TDWLI. Periodic Principal (9) Especially for the periodic TDWLI, upon maturity, the principal will be returned to the Waqif following the chosen timeframe, be it 1,3,6, and 12 months or the time agreed by the Bank and Waqif. For perpetual TDWLI, after PPM has paid off the financing, it can be used to finance other projects following the terms Waqif proposes above.

The second scheme for TDWLI is when funds are channeled into noncommercial financing Mauquf Alaih to finance infrastructure projects or specific assets. More specifically, below is a scheme using an illustration of financing the Isthisna Minihidro Power Plant (PLTM), whose electricity will be sold to PLN:

Economica: Jurnal Ekonomi Islam - Volume 11, Nomor 1 (2020) https://journal.walisongo.ac.id/index.php/economica 
Yaser Taufik Syamlan et al.

Figure 2. Scheme TDWLI for Non Mauquf Alaih.

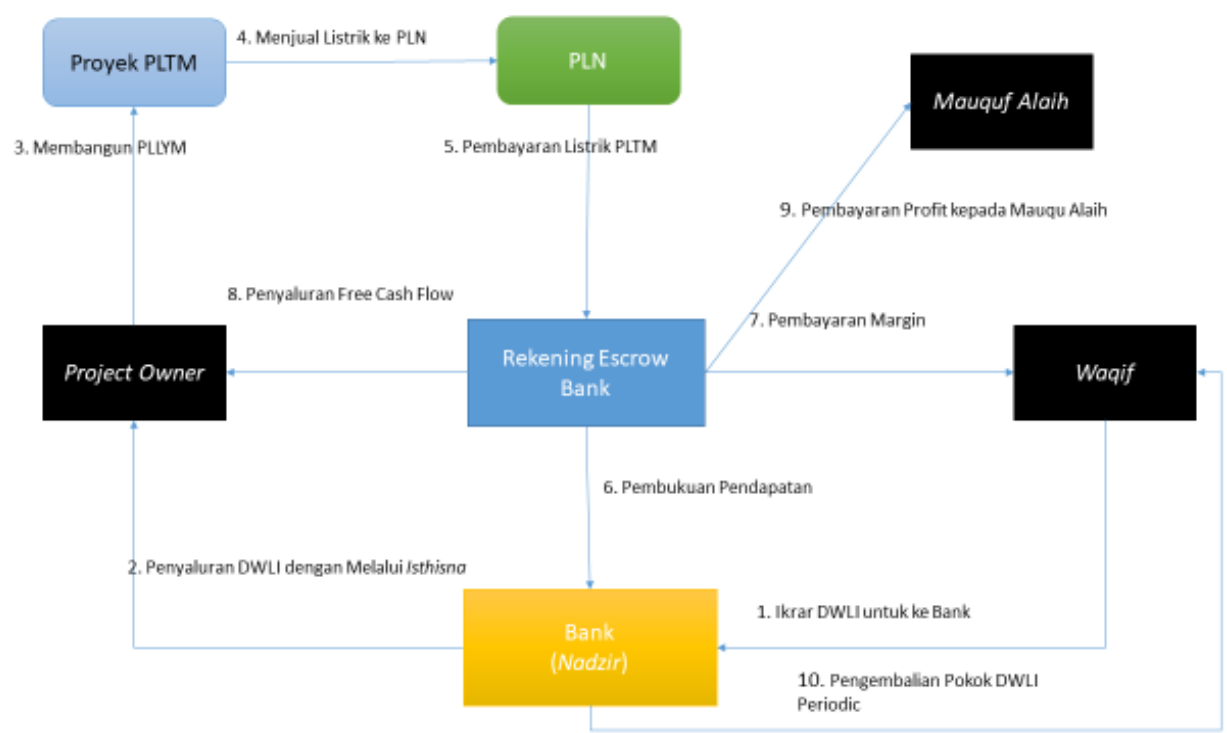

Source: Noor \& Yunus, (2014) with some modifications

In general, the above process is the same as in Figure 2. The primary difference between the two illustrations above is (1) When Waqif makes the TDWLI Pledge to the Bank as Nadzir, it only requires the Bank to manage the TDWLI according to its type. Particularly for TDWLI Periodic/Principal, Waqif must mention Mauquf Alaih from the profit-sharing on payments from PLN. (2) The difference with Figure 2. can be seen in flow No. 9 in Figure 2. when the Bank transfers funds to Mauquf Alaih, who was appointed or mentioned by Waqif when he initially made the Pledge. 


\section{Accounting treatment according to PSAK 104 concerning isthisna and 112 regarding Waqf}

In general, referring to PSAK 112 (IAI 2018) point 12 TDWLI, the type of waqf assets that the Bank will manage as Nadzir is Cash Waqf. The Cash Waqf assets will be channeled to financing under an Isthisna contract following PSAK 104 (IAI, 2015) with the bank's position as the buyer of Isthisna's assets. In the accounting aspect of TDWLI, five important things must be considered. First regarding recognition in Article 17 of PSAK 112 states that Nadzir can only record waqf assets when legally and physically controlling these assets. In the TDWLI context, banks have the right to record using on the balance sheet because legally, the bank accepts the pledge from Waqif and also physically controls the waqf funds.

The second aspect is Measurement. Article 40 PSAK 112 states that waqf assets in the form of money are measured at their nominal value. In the TDWLI case, on the liabilities side, the amount of assets is recognized according to the nominal placement made by Waqif. On the asset side, the asset value written in the bank's statement of financial position corresponds to the principal value of financing Isthisna and the margin value Isthisna. Another thing that should be considered in PSAK 112 concerning Waqf is article 31, which reads

“... 31. The net proceeds from managing and developing waqf assets are in the form of various kinds of income, such as yields, dividends, and other forms of income, after deducting the related expenses...."

Where, according to the explanation above, it can be interpreted that TDWLI Perpetual/Periodic Principal + Profit Sharing; Isthisna margin after deducting operating expenses and PPAP. For example, the Isthisna Margin is $13 \%$, the Overhead Cost $(\mathrm{OHC})$ is $5 \%$, the bank's expected margin is $2.5 \%$, the net return to be returned to this type of pool of funds is 7.5\%. furthermore, TDWLI Peiodic Principal; Assuming that Isthisna Margin is 13\%, OHC is 5\%, and bank's expectation Margin is 2.5\%, the return returned to Waqif is $7.5 \%$ 
Yaser Taufik Syamlan et al.

The third aspect is presentation Referred to in Article 45, Cash Waqf received by Nadzir will be recognized as a liability. In this case, there are differences in the terms used in PSAK 112 and this study. In PSAK 112, cash waqf is referred to as Temporary Waqf, which in this study is the same as the TDWLI Periodic. With the explanation above, for the perpetual TDWLI Perpetual, there are several possible presentations in the Bank's balance sheet. This possibility is to consider it a liability considering that the Bank as Nadzir is obliged to manage and maintain waqf assets in such a way that their value can develop. In this regard, TDWLI Perpetual can be placed in the lowest position because it will not be disbursed.

As listed in Article 46, the fourth aspect is that Nadzir must disclose the (1) Accounting policies used (2) A description of the significant Waqif amount that affects the managed fund. This is important to do, especially in the case of the TDWLI Periodic. (3) An explanation of the waqf management strategy. This can be a plus point for the Bank because a good management strategy will attract other Waqifs to use TDWLI to increase the Bank's assets. (4) An explanation of the allocation of Waqf. (5) Rewards received from Nadzir

The last aspect is Reporting. Banks are required to periodically report each type of TDWLI about article 50 such as: Statement of financial position at the end of the period; a detailed report on waqf assets at the end of the period; Activity reports during the period; Cash flow statement during the period; and Notes to financial statements. 


\section{Operational and risk management analysis}

Table 3.2 Analysis Risk and Operational Analysis TDWLI

\begin{tabular}{|c|c|c|c|}
\hline No & $\begin{array}{l}\text { TYPES OF } \\
\text { RISK RISK }\end{array}$ & ANALYSIS RISK & MITIGATION \\
\hline 1. & Credit Risk & $\begin{array}{l}\text { - Failure of Mauquf Alaih/Project } \\
\text { Owner in returning financing } \\
\text { originating from TDWLI funds }\end{array}$ & $\begin{array}{l}\text { - Third Party Financing Analyst } \\
\text { - Financing Insurance } \\
\text { - Financing Guarantee }\end{array}$ \\
\hline 2. & Market Risk & - TDWLI is not exposed because it is & Cash Waqf \\
\hline 3 & Liquidity Risk & $\begin{array}{l}\text { - Occurs when the TDWLI Periodic } \\
\text { is due } \\
\text { - Withdrawals accelerated by } \\
\text { Waqif }\end{array}$ & $\begin{array}{l}\text { - The bank uses the Allocation of } \\
\text { Fund system } \\
\text { - Other Bank Placements } \\
\text { - Waqif may not withdraw before } \\
\text { maturity }\end{array}$ \\
\hline 4 & $\begin{array}{l}\text { Operational } \\
\text { Risk }\end{array}$ & $\begin{array}{l}\text { - Errors in the analysis of } \\
\text { financing by Nadzir } \\
\text { - Error in calculating Nadzir profit } \\
\text { sharing } \\
\text { - Error in debiting escrow account } \\
\text { - System failure } \\
\text { - Islamic banking human resources } \\
\text { are unable to explain the } \\
\text { characteristics and risks of the } \\
\text { product }\end{array}$ & $\begin{array}{l}\text { - Periodic training for all } \\
\text { stakeholders } \\
\text { - Third party financing analysts } \\
\text { - System maintenance }\end{array}$ \\
\hline 5. & Legal Risk & $\begin{array}{l}\text { - Weak binding transactions } \\
\text { starting from the Pledge process } \\
\text { by Waqif to escrow account } \\
\text { transactions }\end{array}$ & $\begin{array}{l}\text { - Review by an independent legal } \\
\text { office to ensure compliance with } \\
\text { laws and regulations }\end{array}$ \\
\hline 6 & $\begin{array}{l}\text { Reputation } \\
\text { Risk }\end{array}$ & $\begin{array}{l}\text { - When the quality of the project } \\
\text { owner low, making the bank's } \\
\text { reputation declined because the } \\
\text { project is analyzing the Bank }\end{array}$ & $\begin{array}{l}\text { - Monitor the bank's reputation } \\
\text { risk and perform reputation } \\
\text { management. } \\
\text { - Use of an independent financing } \\
\text { analyst }\end{array}$ \\
\hline 7 & Strategic Risks & $\begin{array}{l}\text { - Channeling Isthisna financing to } \\
\text { the declining financing sector }\end{array}$ & $\begin{array}{l}\text { - Banks must conduct continuous } \\
\text { research related to a declining } \\
\text { sector to avoid this. } \\
\text { - Determine the maximum limit of } \\
\text { financing that can be provided } \\
\text { for each sector based on } \\
\text { potential risks. }\end{array}$ \\
\hline 8 & $\begin{array}{l}\text { Compliance } \\
\text { Risk }\end{array}$ & $\begin{array}{l}\text { - The bank does not disclose } \\
\text { information properly }\end{array}$ & $\begin{array}{l}\text { - The Bank has a monitoring team } \\
\text { for information disclosure on } \\
\text { products }\end{array}$ \\
\hline $\begin{array}{c}9 \\
10 .\end{array}$ & $\begin{array}{l}\text { Risk of Return } \\
\text { Investment } \\
\text { Risk }\end{array}$ & \multicolumn{2}{|c|}{$\begin{array}{l}\text { - TDWLI is not exposed to the Risk of Returns and Time Deposits because } \\
\text { the financing uses Isthisna Contract }\end{array}$} \\
\hline
\end{tabular}

Source: Bank Indonesia (2016) \& OJK (2016)

Economica: Jurnal Ekonomi Islam - Volume 11, Nomor 1 (2020) https://journal.walisongo.ac.id/index.php/economica 
Yaser Taufik Syamlan et al.

Referring to POJK No. 65/POJK.03/2016 concerning Implementation of Risk Management for BUS and UUS, there are ten identifiable risks for sharia banking products and services, namely credit, legal, investment, liquidity, operational, reputation, strategic, yield, market risk, and compliance risk. Based on Table 3.2, Islamic Bank will face all risk except market risk, risk of return, and Investment risk since Istisna is not equity-based contract, yet it's the buy and sale contract. The bank might face the credit risk when Mauquf Alaih or the Project Owner (further referred to as debit) cannot meet Isthisna's installment payments to the Bank. A mitigation step is to use a financing guarantee system and request additional liquid guarantees from the Debtor.

The Liquidity risk will arise, especially in TDWLI periodic products, which can be withdrawn at maturity. In this case, the Bank can fail to pay its obligations to Waqif because the debtor has not paid Isthisna financing or there is an accelerated disbursement made by Waqif. As a solution to this problem, Banks can borrow funds at the Islamic Interbank Money Market (PUAS). In addition, when Waqif signs the TDWLI contract, a clause must also be attached, stating that Waqif is not allowed to withdraw TDWLI before disbursement. This risk is also closely related to the mismatch between assets and liabilities, so according to Darsono et al. (2015), the Bank is expected to implement a new system, namely the Allocation of Fund to replace the Pool of Fund. This new system will be beneficial for TDWLI, mainly because there are types of Perpetual products that cannot be combined because they are permanent Waqf.

Banks face operational risks due to errors in financing analysis, profit sharing calculations, debating of escrow accounts, system failures, and Islamic banking human resources' failure who cannot correctly explain the characteristics of transactions and product risks. To mitigate this, the Bank is obliged to conduct periodic training for the parties involved. In addition, to minimize the risk of errors in financing analysis, the parties involved can use the services of independent financing analysts. Periodic system maintenance 
is also mandatory as an anticipatory step so that this risk does not occur in the future. The system problem becomes crucial because if the product is TDWLI Perpetualimplemented, the Bank will need several adjustments due to its different features on deposits in general, which are returned when due.

Banks face legal risks when the rights and obligations of the parties are not well explained when the binding is not done perfectly (especially during the Waqf Pledge and in the escrow account agreement). Mitigation of the legal risk mentioned above, the review can be carried out by an independent law office, especially for Waqifs who choose TDWLI Periodic with a sizeable nominal amount. The Reputation risk. Banks face reputational risk when there are projects that get stuck or cannot be executed properly. To mitigate this, the use of independent financing analysts can minimize the chances that will occur. In addition, the Bank also needs to manage the bank's reputation in the eyes of stakeholders.

Banks face strategic risks when providing financing to a declining financing sector. As a precautionary measure, the bank can regularly analyze the declining financial industry through financing division and/or corporate planning divisions (Corporate Planning). By performing this update, the risk is not the case and set a maximum limit of financing that can be given to each each sector based on the potential risk. Last, the bank faces the compliance risk faced by the bank due to the bank not complying and/or not implementing the prevailing laws and regulations as well as sharia principles. Concerning this transaction, compliance with sharia law becomes essential, especially about the bank's position, Nadzir when channeling financing to the non-halal sector. To mitigate this, the sharia compliance division must be lowered for significant nominal financing. To mitigate compliance risk, the Bank must have a special team to ensure good information disclosure. 
Yaser Taufik Syamlan et al.

\section{Conclusion}

In conclusion, This study offers four types of TDWLI product variants, namely TDWLI Perpetual Principal, TDWLI Perpetual Principal + Profit Sharing, TDWLI Periodic Principal, TDWLI Periodic Principal, and + Profit Sharing. Of the four variants, the TDWLI Periodic Principal is the variant that is most ready to be applied because, in accounting terms, it has been regulated in PSAK 112. In general, this TDWLI product will provide several benefits for banks to reduce the cost of funds (especially for the main variant of Waqf only) and increase Isthisna financing, which refers to the OJK data for 2019 to only $0.3 \%$ of the total financing.

To smoothly run the business of TDWLI, in terms of accounting treatment, PSAK 112 must be adjusted significantly if the Bank is to release a Perpetual-based product variant. The main problem with perpetual-based products is the uncommon features where in perpetual, cash waqf cannot be withdrawn or, in other words, eternal. Another thing that stakeholders must consider is the obligation to disclose information on Waqf, which is quite a time-consuming for the bank, considering that PSAK 112 requires disclosure of the allocation of funds. Finally, the most challenging part is the periodic reporting of all Bank activities as Nadzir to the public.

Islamic banks also should put risk management a priority by analyzing it from time to time. As of the ten risks regulated in POJK No. 65/POJK.03/2016 concerning Implementation of Risk Management for BUS and UUS, Risks that must be considered by Banks more seriously are Credit Risk, Liquidity, and Reputation. Banks must ensure that the debtor who receives financing from the TDWLI Fund is a competent party so that the risk of congestion can be reduced. This credit risk will have a broad impact on other risks, such as the failure of the Bank to meet the disbursement demands of TDWLI (especially TDWLI Periodic), and the bank's reputation Nadzir will decline. To mitigate this problem, the Bank may appoint independent financing analysts and 
independent consultants to carry out more in-depth financing analysis and close monitoring of all financing provided.

\section{References}

AAOIFI. 2015. Accounting, Auditing and Governance Standards. Edited by AAOIFI. December 2. Manama, Bahrain: Accounting and Auditing Organization for Islamic Financial Institutions.

Ahmad, Ziauddin. 1987. "Waqf as An Instrument of Perpetuity - An Assessment." Islamic Studies 26 (2): 123-42.

BNM, Bank Negara Malaysia. 2014. "Istisna `Concept Paper."

Candra, Hari, and Asmak Ab Rahman. 2010. "Waqf Investment: A Case Study of Dompet Dhuafa Republika, Indonesia." Jurnal Syariah 18 (1): 163-90.

Cizakca, Murat. 2014. "Cash Waqf of Bursa, 1555 - 1823." Journal of the Economic and Social History of the Orient 38 (3): 313-54.

Darsono, Ali Sakti, Ascarya, Siti Aisyah, Harisman, Androecia Darwis, Enny Tin Suryanti, and Siti Rahmawati. 2017. Perbankan Syariah Di Indonesia: Kelembagaan Dan Kebijakan Serta Tantangan Ke Depan. Edited by Muhammad Syafii Antonio. 1st ed. Depok: PT. Rajagrafindo Persada.

Farrukh, Muhammad Zeeshan. 2010. "The Analysis of Application of Salam \& Istisna' A In Islamic Financial Industry." Attijarah Center of Islamic Economic.

Fuadi, Nasrul Fahmi Zaki. 2018. "Wakaf Sebagai Instrumen Ekonomi Pembangunan Islam." Economica: Jurnal Ekonomi Islam 9 (1): 151. https://doi.org/10.21580/economica.2018.9.1.2711.

Hanif, Muhammad. 2016. "Economic Substance or Legal Form: An Evaluation of Islamic Finance Practice." International Journal of Islamic and Middle Eastern Financial Management 9 (2): 277-95. https://doi.org/10.1108/IMEFM-07-2014-0078.

Hasmawati, Anisza, and Azhar Mohamad. 2019. "Potential Application of Istisna' Financing in Malaysia." Qualitative Research in Financial Markets 11 (2): 211-26. https://doi.org/10.1108/QRFM-07-2018-0083.

IAI, Ikatan Akuntan Indonesia. 2018. "Draft Eskposur PSAK 112 Akuntansi Wakaf." Jakarta.

Economica: Jurnal Ekonomi Islam - Volume 11, Nomor 1 (2020)

https://journal.walisongo.ac.id/index.php/economica 
Yaser Taufik Syamlan et al.

Ismail Abdel Mohsin, Magda. 2013. "Financing through Cash-Waqf: A Revitalization to Finance Different Needs." International Journal of Islamic and Middle Eastern Finance and Management 6 (4): 304-21. https://doi.org/10.1108/IMEFM-08-2013-0094.

Ismal, Rifki. 2014. "An Optimal Risk - Return Portfolio of Islamic Banks." Humanomics 30 (4). https://doi.org/10.1108/H-08-2013-0055.

Loeb, Susanna, Susan Dynarski, Daniel McFarland, Pamela Morris, Sean Reardon, and Sarah Reber. 2017. "Descriptive Analysis in Education: A Guide for Researchers." U.S. Department of Education, Institute of Education Sciences. National Center for Education Evaluation and Regional Assistance.

Manzoor, Davood, Majid Karimirizi, and Ali Mostafavisani. 2017. "Financing Infrastructure Projects Based on Risk Sharing Model: Istisna Sukuk." Journal of Emerging Economies and Islamic Research 5 (3): 72-84.

Medias, Fahmi, Eko Kurniasih Pratiwi, and Khotibul Umam. 2019. "Waqf Development in Indonesia: Challenges Faced by Muhammadiyah Waqf Institutions." Economica: Jurnal Ekonomi Islam 10 (2). https://doi.org/10.21580/economica.2019.10.2.3333.

Mukhlisin, Murniati, Mohammad Hudaib, and Toseef Azid. 2015. "The Need for Shariah Harmonization in Financial Reporting Standardization the Case of Indonesia." International Journal of Islamic and Middle Eastern Finance and Management 8 (4): 455-71. https://doi.org/10.1108/IMEFM-10-2013-0110.

Noor, Azman Bin Mohd, and Saidatolakma Bt Mohd Yunus. 2014. "Application of the Build, Operate, Transfer (BOT) Contract as a Means of Financing Development of Waqf Land: Malaysian Experience." Arab Law Quarterly 28 (2): 136-57. https://doi.org/10.1163/15730255-12341281.

Raimi, Lukman, Ashok Patel, and Ismail Adelopo. 2014. "Corporate Social Responsibility, Waqf System and Zakat System as Faith-Based Model for Poverty Reduction." World Journal of Entrepreneurship, Management, Sustainability Developmen $10 \quad$ (3): 228-42. https://doi.org/10.1108/WJEMSD-09-2013-0052.

Rosly, Saiful Azhar. 2010. "Shariah Parameters Reconsidered." International Journal of Islamic and Middle Eastern Finance and Management 3 (2): 132-46. https://doi.org/10.1108/17538391011054372. 
Standar, Dewan, Akuntansi Syariah, Ikatan Akuntan Indonesia, and Grha Akuntan. 2015. "PSAK Akuntansi Istishna'," no. 1.

Tanjung, Hendri. 2018. "An Integration of Waqf and Ventura Capital: A Proposed Model for Indonesia." Journal of Islamic Monetary Economics and Finance 3 (Special Issue): 125-40.

Thoarlim, Abdulsoma, Asadur Rahman, and Anas Yanya. 2017. "Cash Waqf in Bangladesh and the Need for Innovative Approach towards Awqāf: Lessons from Selected Countries" 7 (4): 151-69. https://doi.org/10.6007/IJARBSS/v7-i4/2795.

Zarqa, Muhammad Anas. 1997. "Istisna' Financing Of Infrastructure Projects" Islamic Economic Studies 4 (2): 2-9. 
Yaser Taufik Syamlan et al. 